\title{
Getting the Foundations Right: Alberta's Approach to Healthcare Reform
}

\section{Construire des fondations solides : démarche face à la réforme de la santé en Alberta}

\author{
STEPHEN DUCKETT, PHD, DSC \\ Former President and Chief Executive Officer, Alberta Health Services \\ Adjunct Professor, Department of Community Health Sciences \\ University of Calgary \\ Calgary, $A B$
}

\begin{abstract}
Alberta's abolition of its health regions and the creation of Alberta Health Services in 2008 has integrated previously disparate providers of healthcare services. The long-term benefits of this "second-wave" approach to health systems structuring include lower administrative costs, greater equity of access, improved intraprovincial learning and economies of scale. Some benefits have begun to be realized but, as with any merger, performance should be judged over a multi-year time frame.

\section{Résumé}

L'abolition des autorités sanitaires régionales en Alberta et la création d'Alberta Health Services en 2008 a conduit à l'intégration d'une variété de fournisseurs de services de santé auparavant séparés. Les avantages à long terme de cette « deuxième vague » de structuration des systèmes de santé comprennent des coûts administratifs moins élevés, une plus grande égalité d'accès, un meilleur apprentissage intraprovincial et des économies d'échelle. Certains avantages commencent à prendre forme mais, comme dans toute fusion, il faudrait évaluer le rendement sur une période couvrant plusieurs années.
\end{abstract}




\section{The merger of the i2 former health entities previously Responsible for healthcare delivery in Alberta (population less than 4 million) has attracted a lot of attention across Canada, including Cameron Donaldson's critique in a recent issue of} Healthcare Policy/Politiques de santé (Donaldson 2010). Despite the title of his paper, the creation of Alberta Health Services (AHS) cannot by any stretch of the imagination be described as "disintegration." Rather, this integration of previously disparate entities offering mental health, addictions, cancer and emergency medical services with those provided by the former regions will be one of the long-term benefits of the merger.

Donaldson identifies three "real questions" that provide a good framework for both his paper and this response:

- Why did Alberta make such a move?

+ How did the province intend to achieve its stated aims?

- Did it in fact achieve these? (Donaldson 2010: 23)

Alberta is a relatively high-spending province in terms of age-gender adjusted per capita public health expenditure (based on CIHI data). But its health-adjusted life expectancy is below the Canadian average, and it is on the wrong side of the Canadian average on most access measures, patient satisfaction and a number of outcome measures (Duckett et al. 2011). So, clearly, change of some kind is necessary.

As Donaldson points out, there were other problems with the previous structures:

- "It may well be that the health regions in Alberta were culpable for not coming to grips with how to manage their fixed funding envelopes in order to best meet population needs." (Donaldson 2010: 28)

+ "... that rather than a failure of the regional structures that were in place, what Alberta experienced was a failure of leadership, not only of the regions but also at the political level." (Donaldson 2010: 29)

Alberta was not the first political entity to recognize that regional experiments were failing, and Saltman (2008) has argued that the recentralization occurring in a number of countries may herald the start of the next "long wave" of structural reform. Alberta's new model is consistent with this "second-wave" approach to health system structuring and is likely to have similar benefits and challenges (Duckett 2010).

\section{Administrative Costs}

Donaldson highlights and dismisses one justification for integration - relatively higher administrative costs (Donaldson 2010: 24-25). The data he advances are for administrative costs relative to total public and private expenditure, which is influenced by many factors, including policy and personal choices not affected by efficiency (or non-efficiency) of entities charged with delivery of public services. However, even using this measure, Alberta might be high- 
lighted for further scrutiny: as would be expected given likely scale economies, the three larger provinces are the cheapest in terms of per capita administrative costs, but three smaller provinces are also cheaper than Alberta.

But administrative costs are one of the prime areas where benefits might be seen. Every previous entity, for example, would have its own chief financial officer, human resources group and so on. Economies of scale are to be expected in areas with significant numbers of transactions.

Many administrative savings can be realized relatively quickly, especially through the elimination of duplicate senior positions. Because each of the former health entities was required to publish information about salary costs of staff annually, as is AHS, it is possible to compare costs of senior management staff before and after the merger.

Table 1 (http://www.longwoods.com/content/22176) shows spending on the top three management levels of AHS (in 2009/10 dollars) and the former health entities (2007/08 data, the last year before the merger). There has been about a $9 \%$ rise in salaries since then (4.5\% in 2008/09 and 4.3\% in 2009/10), so the data here underestimate the differences pre- and post-merger. Unfortunately, the guidance for these reports led to some variability in reporting (e.g., Capital Health didn't report any managers reporting at the third level).

The table shows that AHS expenditure on senior management is less than $30 \%$ of the aggregate of the former entities. So despite having a vice-president for cancer care included in the above numbers (Donaldson 2010: 24), the other infrastructure of the former Cancer Board has not been duplicated in the new AHS structure.

\section{Merger Benefits}

Donaldson's second question asks how we would expect to achieve benefits from the merger. There are three main types of changes that should lead to benefits over time.

First is intraprovincial equity. The previous regional health authorities made local decisions, reflecting local priorities. Inevitably, the decisions differed. In turn, this meant different services were expanded (or existed) in different regions, and Albertans had differential access to services depending on where they lived. Cataract surgery is a case in point. The former Calgary Health Region funded fewer cataract operations than the former Capital Health Region. The consequence was longer wait times in Calgary compared to Edmonton. It is now the job of AHS to iron out these differences.

The second benefit is improved intraprovincial learning. The previous entities had national reputations for innovation in many fields, but these innovations often did not flow across the province. If a good idea is generated and implemented in Grande Prairie, it should be implemented in Medicine Hat, and so on. The demise of regional rivalries helps here, but so too does AHS's new structures (e.g., in two cases senior vice-presidents are responsible for hospitals in both Edmonton and Calgary, and one senior vice-president is responsible for all regional hospitals). AHS has also established clinical networks to take a provincial perspective.

The third benefit relates to efficiencies and economies of scale. AHS has already accrued significant benefits from the merger in procurement savings, and Table 1 displays the benefits of scale economies in terms of leadership positions. The larger scale also allows AHS to do 
things that no other health authority in Canada can do.

Three examples:

- Alberta Health Services is moving to introduce activity-based funding in a number of areas. Activity-based funding (erroneously described by Donaldson as "case-based costing") involves developing a formula to take account of the different needs of a patient or resident and then funding the service or hospital according to those needs. The cost for a hospital patient who has a transplant is obviously more than the cost for removing an appendix, and the hospital that does more of the former should have a larger budget for treating those patients. Activity-based funding works best when there are multiple organizations to compare and contrast. You need a largish number of organizations to participate in activity-based funding to develop a sensible system and effective funding formulx, with appropriate comparisons and benchmarks.

- A second example is the creation of a single acute care provincial drug formulary. The previous nine health regions and the Alberta Cancer Board each maintained separate drug formularies for use within its own area of control. This approach resulted in significant duplication of effort related to the evaluation and addition of drugs to the formulary, and to maintenance of systems associated with drug use. Alberta is now the only province with a single acute care formulary. Having a single provincial drug formulary improves patient care and safety by ensuring that optimal drug therapies are utilized. It also reduces safety risks associated with employees who work for more than one health service (each with a different formulary), minimizes duplication and realizes financial savings from contract consolidation.

- Analysis and promotion of safety is yet another example. AHS can now compare safety performance across a number of hospitals using statistical process-control approaches. Again, this strategy relies on having enough information from a larger number of hospitals to provide robust benchmarks.

\section{Achievements}

Finally, Donaldson questions achievement. Unfortunately, it is too early to expect to see measurable benefits in access or outcomes at this stage.

AHS is now the largest publicly funded healthcare provider in Canada, by a significant margin. The full benefits of the merger should not be expected to be seen within a year. Shifting priorities and rolling out lessons from one part of the province to another will take time. As indicated above, some benefits have already begun to be realized, but as with any merger, benefit realization should be judged over a multi-year time frame.

Alberta's previous structural initiatives were watched closely by the other provinces and have been the subject of academic evaluations (Hinings et al. 2003; Philippon and Wasylyshyn 1996; Reay and Hinings 2005). Such scrutiny is welcomed and encouraged. But academic (as opposed to journalistic) critique should be undertaken over a reasonable time frame. Donaldson's pessimistic conclusions and predictions about the AHS merger are way 
too premature and thus cannot be soundly based.

Readers would be well advised to withhold judgment about the AHS merger until a more rigorous evaluation is possible.

\section{REFERENCES}

Donaldson, C. 2010. “Fire, Aim... Ready? Alberta’s Big Bang Approach to Healthcare Disintegration." Healthcare Policy/Politiques de santé 6(1): 22-31.

Duckett, S. 2010 (Winter). "Second Wave Reform in Alberta." Healthcare Management Forum 23(4): 156-58. doi:10.1016/j.hcmf.2010.08.006.

Duckett, S.J., G. Kramer et al. 2011. "Alberta's Health Spending Challenge: A Policy-Oriented Analysis of Interand Intra-Provincial Differences in Health Expenditure." In D. Ryan, ed., Boom and Bust Again: Policy Challenges for a Commodity Based Economy. Edmonton: University of Alberta Press.

Hinings, C.R., A. Casebeer et al. 2003 (December). “Regionalizing Healthcare in Alberta: Legislated Change, Uncertainty and Loose Coupling." British Journal of Management 14 (Suppl. 1): S15-S30.

Philippon, D.J. and S.A. Wasylyshyn. 1996. "Health-Care Reform in Alberta." Canadian Public Administration 39(1): 70-84.

Reay, T. and C.R. Hinings. 2005."The Recomposition of an Organizational Field: Health Care in Alberta." Organization Studies 26(3): 351-84.

Saltman, R.B. 2008. “Decentralization, Re-centralization and Future European Health Policy.” European Journal of Public Health 18(2): 104-6. 
Getting the Foundations Right: Alberta's Approach to Healthcare Reform

TABLE 1. Remuneration for senior management staff of former health entities, year ending through 2008, AHS year ending March 2010 (\$'000s)

\begin{tabular}{|c|c|c|c|c|c|c|c|c|c|c|c|c|c|c|}
\hline & \multicolumn{13}{|c|}{ Former health entities, 2008/09 } & \multirow[t]{2}{*}{ AHS } \\
\hline & Chinook & Palliser & Calgary & $\begin{array}{l}\text { David } \\
\text { Thompson }\end{array}$ & $\begin{array}{l}\text { East } \\
\text { Central }\end{array}$ & Capital & Aspen & $\begin{array}{l}\text { Peace } \\
\text { Country }\end{array}$ & $\begin{array}{l}\text { Northern } \\
\text { Lights }\end{array}$ & $\begin{array}{l}\text { Cancer } \\
\text { Board }\end{array}$ & $\begin{array}{c}\text { Alberta } \\
\text { Mental } \\
\text { Health Board }\end{array}$ & $\begin{array}{l}\text { Alberta Alcohol } \\
\text { and Drug Abuse } \\
\text { Commission }\end{array}$ & Subtotal & \\
\hline $\begin{array}{l}\text { President \& } \\
\text { CEO }\end{array}$ & 565 & 454 & ।,335 & 422 & 170 & 915 & 305 & 360 & 380 & 712 & 282 & 289 & 6,189 & 744 \\
\hline $\begin{array}{l}\text { Other board } \\
\text { and CEO } \\
\text { direct reports }\end{array}$ & ।,864 & ।,205 & 4,332 & 1,516 & ।,084 & 3,095 & 983 & 1,584 & 1,583 & 2,343 & 838 & 517 & 20,944 & 5,063 \\
\hline $\begin{array}{l}\text { Managers } \\
\text { directly } \\
\text { reporting to } \\
\text { above }\end{array}$ & ।,684 & 3,666 & 5,361 & 5,787 & 2,054 & - & 3,804 & 1,160 & ।,155 & 4,207 & ।,492 & - & 30,370 & $|0,69|$ \\
\hline Total & 4,113 & 5,325 & 11,028 & 7,725 & 3,308 & 4,010 & 5,092 & 3,104 & 3,118 & 7,262 & 2,612 & 806 & 57,503 & 16,498 \\
\hline
\end{tabular}

